\title{
Assessment of energy and macronutrient intake in young men: a comparison of 4-day food record and 24-hour dietary recall
}

\author{
Quantificação do consumo energético e de \\ macronutrientes em homens jovens: uma \\ comparação de 4 dias de registros alimentares \\ e recordatório alimentar de 24 horas
}

e recordatorio alimentar de 24 horas

Selma Coelho LIBERATO ${ }^{1,2}$

Josefina BRESSAN²

Andrew Peter HILLS 3

A B S T R A C T

\section{Objective}

The objective was to assess the quantitative agreement between a 4-day food record and a 24-hour dietary recall in young men.

\section{Methods}

Thirty-four healthy men aged 18-25 years had their food intake estimated by 4-day food record within one week following 24-hour dietary recall in a cross-sectional study. Resting metabolic rate was assessed by indirect calorimetry and Energy Expenditure was estimated by physical activity records completed simultaneously with food intake records. The validity of food records was determined by direct comparison of Energy Intake and Energy Expenditure (95\% confidence interval for Energy Intake/Energy Expenditure).

\section{Results}

There were good agreements between the measurements of energy and macronutrient intakes by 24-hour dietary recall and 4-day food record at the group level, but not at the individual level. Compared to energy expenditure, about $20 \%$ and $9 \%$ of participants underreported their Energy Intake by 4-day food record and 24-hour dietary recall, respectively. Over 30\% of underreporters of Energy Intake estimated by 24-hour dietary recall underreported Energy Intake estimated by 4-day food record.

${ }^{\mathbf{1}}$ Menzies School of Health Research. Casuarina, NT 0811, Australia.

2 Universidade Federal de Viçosa, Departamento de Nutrição e Saúde. Av. PH Rolfs, s/n., 36571-000, Viçosa, MG, Brazil.

Correspondência para/Correspondence to: J. BRESSAN. E-mail: <jbrm@ufv.br>.

3 Queensland University of Technology, Institute of Health and Biomedical Innovation, School of Human Movement Studies. Campus Kelvin Grove, Brisbane, Australia. 
622 S.C. LIBERATO et al.

\section{Conclusion}

Both diet methods, 24-hour dietary recall and 4-day food record, may be used to collect data at the group level, but not at the individual level. Both methods, however, appear to underestimate Energy Intake. Underreporting may be subject-specific and appears that is more difficult to retrieve valid dietary data from some people than others.

Indexing terms: Diet report. Energy consumption. Food records. Underreporting.

\section{RE S U M O}

\section{Objetivo}

Medir a concordância qualitativa entre registros alimentares, obtidos durante 4 dias, e recordatório alimentar de 24 horas em homens jovens.

\section{Métodos}

Em um estudo com delineamento transversal, o consumo alimentar de 34 homens saudáveis com idades entre 18 e 25 anos foi medido por meio do recordatório alimentar de 24 horas e uma semana depois, por meio de 4 dias de registros alimentares. O gasto energético em repouso foi medido por calorimetria indireta e o gasto energético total foi medido por meio de registros de atividade física. A validade dos registros alimentares foi determinada por comparação direta do consumo energético com o gasto energético total (intervalo de confiança de $95 \%$ para consumo energético/gasto energético total).

\section{Resultados}

A concordância entre medidas de consumo energético e de consumo de macronutrientes, obtida por meio de registros alimentares de 4 dias e por recordatório de 24 horas, foi boa para grupos, mas não para indivíduos. Comparado com o gasto energético total, um baixo consumo energético foi observado em $20 \%$ e em $9 \%$ dos participantes, quando o consumo alimentar foi obtido por meio de registros alimentares de 4 dias e por recordatório de 24 horas, respectivamente. Mais de 30\% dos participantes que tiveram baixo consumo energético, obtido com a utilização de recordatório de 24 horas, também tiveram baixo consumo energético a partir do exame dos registros alimentares de 4 dias.

\section{Conclusão}

O recordatório de 24 horas é uma opção para registros alimentares de 4 dias na coleta de dados para grupos, mas não para indivíduos. Entretanto, baixo consumo alimentar, em alguns participantes, foi observado quando ambos os métodos foram utilizados na coleta de dados de consumo alimentar. É possível que a determinação de baixo consumo alimentar em alguns participantes seja específica do participante, sugerindo que pode ser mais difícil obter dados precisos de umas pessoas do que de outras.

Termos de indexação: Registros de dieta. Consumo de energia. Inquéritos alimentares. Subregistro.

\section{N T R O D U C T IO N}

Accurate measurements of food intake are important to studies of the association between diet and health'. A method often used in large surveys due to its short administration time is the 24-hour Dietary Recall Method (24hDR), where during an interview, the participant tells the interviewer the quantity of foods and beverages consumed in the preceding day. This method has a relatively small participant burden, participants' food intake pattern is unchanged and the collected data are more reliable due to the personal contact with the interviewer. However, the participants' recall depends on memory.

The self-report method, where the participants record all food and beverages consumed during a period of time, usually ranging from 1 to 7 days, is probably the most accurate of the self-report methods. However, the disadvantages include the burden to respondent of the recording process and the possibility of the habitual intake to be changed ${ }^{2,3}$. The amount of consumed food can be estimated visually or previously weighed. 
Methods where the amount of food consumed is weighed previously are the most accurate. However, their use is time consuming, requires a high level of participants' cooperation and is cumbersome for free-living participants. The estimation of the amount of food is rapid, has low cost, has high cooperation rates and is less demanding for participants than weighing foods $s^{4,5}$. However, the accuracy of estimating food is highly variable among participants according to subject's skills, memory and commitment to the study. Previous training improves the food portion estimates ${ }^{6}$.

Many studies have evaluated the relative validity of the diet assessment methods and the agreement between the methods has typically been summarised by calculation of the correlation, regression coefficients or degree of crossclassification. Indeed, no study has actually focused on the absolute agreement between the methods and the individual variation of the between-method differences in young men.

In addition, it has been established for many years that comparisons between methods are not sufficient, since individuals report similarly with different methods. Therefore, the aim of the present study was quantitatively to test the agreement between estimated nutrient intake obtained with $24 \mathrm{hDR}$ recall and 4-day food record ( $4 \mathrm{dFR})$ methods in a sample of young men comparing the food intake methods against energy expenditure.

\section{METHODS}

Thirty-four healthy young men aged between 18 and 25 years were recruited between July 2004 and March 2005, from the local community in the city of Brisbane, Australia through newspaper advertisements, flyers in clubs, schools, universities and fitness centers. Each participant read and signed an approved written consent form. Queensland University of Technology Human Research Ethics Committee approved the participant recruitment and the data collection procedures.

The $24 \mathrm{hDR}$ and coding of records were performed by the same trained dietitian. The $24 \mathrm{hDR}$ comprised four steps. Firstly, the interviewe was asked to recall foods consumed in the previous day. In the second pass, the interviewer probed for estimations with household measures and details about each of the foods and fluids listed. On the third pass, individually the participant saw 48 food item slides each with 3 food sizes expressed on household measures on a computer screen. On the fourth pass the participant had an opportunity to correct and/or complete any inaccurate or forgotten data in his previous recall.

The 4-day food record was completed within one week after the $24 \mathrm{hDR}$ and participants recorded food intake estimated by household measures during the same 4 days while completing the physical activity record. The period of recording included two weekdays, a Saturday and a Sunday.

The $24 \mathrm{hDR}$ and $4 \mathrm{dFR}$ data were entered into the Foodworks ${ }^{\oplus}$ (v. 3.02) nutrient analysis software (Xyris software Pty Ltd., Brisbane, Australia, http://www.xyris.com.au) incorporating nutrient tables for use in Australia (AUSNUT, Canberra, 2000). Dietary records were checked by a dietitian and details regarding recipes and portion sizes were noted and clarified with each participant. Macronutrients were expressed as absolute intakes and energy adjusted volumes (percentage of daily energy intake).

Resting metabolic rate was assessed by a continuous open-circuit indirect calorimetry device. Respiratory gases were collected continuously for 30 minutes and the data from the last 10 minutes were used for analyses. Participants lay supine in a comfortable position, listening to a radio to prevent sleeping whilst monitored to ensure that they remained awake.

Data collection took place in a thermalregulated environment with minimal light and noise. Participants fasted for 5 hours, were involved in minimal physical activity prior to arrival and 
rested lying for $30 \mathrm{~min}$ in the laboratory before the measurement. A Deltatrac II metabolic cart (Datex-Ohmeda Corp., Helsinki, Finland - http:// www. datex-ohmeda.com) was used to assess RMR of half of the participants. Expired gas was analyzed for oxygen concentration via a paramagnetic $\mathrm{O}_{2}$ sensor and for carbon dioxide concentration via an infrared absorption technique. Due to technical problems, the Moxus $\mathrm{O}_{2}$ system (AEI Technologies, Pennsylvania, USA) was used to assess the RMR of the remaining participants. Participants were fitted with a Hans-Rudolf headset (with two-way breathing valve and pneumotach) and a nose clip.

Both gas analyzers were calibrated prior to each measurement against standard mixed reference gases. There are unlikely to be any significant differences in measuring RMR with two different machines because they are continuous open-circuit indirect calorimetry devices that measure oxygen and carbon dioxide concentrations using similar sensors. The Weir equation ${ }^{7}$ was used to convert $\mathrm{O}_{2}$ and $\mathrm{CO}_{2}$ values to RMR values.

$R M R=\left[\left(1.106 \mathrm{VCO}_{2}(\mathrm{~L} / \mathrm{min})+3.941 \times \mathrm{VO}_{2}\right.\right.$ $(L / \mathrm{min})] \times 1440 \mathrm{~min} / \mathrm{d}$, where RMR is the resting metabolic rate $\left(\mathrm{kcal}^{-\mathrm{d}^{-1}}\right), \mathrm{VCO}_{2}$ is the carbonic dioxide production rate and $\mathrm{VO}_{2}$ is the oxygen consumption rate.

\section{Daily energy expenditure}

A 4-day physical activity record ${ }^{8}$ was completed simultaneously with recording food intake. Physical activity was recorded (1-9, corresponding to nine categories of physical activity intensity) for each 15-min period, throughout the day. These categories and their corresponding list of activities, as established by Bouchard et $a^{/}{ }^{3}$. were explained and illustrated in detail to each participant before they started to record.

The daily EE was calculated after accounting, for each 15-min period of a day and multiplying the score by its specific metabolic equivalent (MET). The 4-day physical activity record scores
$1,2,3,4,5,6,7,8$ and 9 correspond to 1, 1.5, $2.3,2.8,3.3,4.8,5.6,6$ and 7.8 METs, respectively.

\section{Evaluation of the validity of food intake methods}

The participants were asked to maintain a normal diet and there were no significant changes in their weight before and after recording food intake suggesting that participants in this study were in energy balance and therefore the validation is by direct comparison of Energy Intake (EI) with Energy Expenditure (EE) expressed as the ratio El:EE. The expected ratio is 1.00 and the 95\% Confidence Limits (CL) are based on mean within-subject variation on daily El intake $\left(\mathrm{CV}_{\text {wE }}\right)$ and on within-subject variation in $\mathrm{EE}\left(\mathrm{CV}_{\text {wEE }}\right)$.

$\mathrm{CL}(\mathrm{EI})_{0.95}=\mathrm{EE}\left[ \pm 2\left(\mathrm{CV}_{\text {wEl }}{ }^{2} / \mathrm{d}+\mathrm{CV}_{\text {WEE }}\right)^{2 / 2}\right]$ where $\mathrm{CV}_{\text {wEI }}$ is the within-subject variation in $\mathrm{El}, \mathrm{d}$ is the number of days of diet assessment ${ }^{9,10}$ and $C V_{\text {wEE }}$ is the within-subject variation in Pooled mean $C V_{w}=\left(\Sigma C V_{i}^{2} / n\right)^{1 / 2}$, where $C V_{i}$ is the $C V$ $\left(\mathrm{CV}_{\text {wEI }}\right.$ or $\left.\mathrm{CV}_{\text {wEE }}\right)$ calculated for each participant from the number of days of dietary assessment or EE assessment available for that participant, and $n$ is the number of participants ${ }^{11}$. In the current study, mean within-subject variation on daily $\mathrm{El}$ intake $\left(\mathrm{CV}_{\text {wEI }}\right)$ was $23 \%$ and on within-subject variation in $\mathrm{EE}\left(\mathrm{CV}_{\text {wEE }}\right)$ was $15 \%$.

Although $\mathrm{El}$ is a continuous, quantitative limits were defined to identify the under-reporters (URs), acceptable reporters (ARs) and overreporters.

When El was estimated by 4dFR, ARs were defined as having the ratio $E / / E E$ in the range 0.62-1.38, URs as El/EE $<0.62$, and over-reporters as El/EE $>1.38$.

When El was estimated by $24 \mathrm{hDR}$, ARs were defined as having the ratio $\mathrm{El} / \mathrm{EE}$ in the range 0.45-1.55, URs as El/EE $<0.45$, and over-reporters as $\mathrm{El} / \mathrm{EE}>1.55$.

Data are presented as means and standard deviation (SD). Differences between URs and ARs 
were evaluated with the use of the Student's test. Calculation of correlation coefficients are inappropriate to test the degree of agreement between two diet methods' ability to measure daily energy and macronutrient intake in the same individuals since they only measure the strength of a relation between the two measurements and not the quantitative agreement between them ${ }^{12}$.

To give quantitative estimates of the agreement between the two methods, BlandAltman plots were constructed to illustrate the distribution of error scores (4dFR - 24hDR - estimated nutrient intake). Solid horizontal lines in theses plots indicate mean error scores, whereas dashed horizontal lines present the 95\% confidence intervals for the error scores. The analyses were conducted using the Statistic for Windows 5.5 software.

\section{RE S U LTS}

The characteristics of the participants are shown in Table 1. The participants had a mean age of 21.4 years, with a mean Body Mass Index (BMI) of $24.83 \mathrm{~kg} / \mathrm{m}^{2}$.

The $24 \mathrm{hDR}$ and $4 \mathrm{dFR}$ provided similar estimates of average daily energy and macronutrient intake expressed as energy source (Table 2). However, there were large variations between $4 \mathrm{dFR}$ and $24 \mathrm{hDR}$ estimates at the

Table 1. Anthropometric characteristics, body mass index, resting metabolic rate, daily energy expenditure, physical activity level, daily energy intake and cut-off limits of 34 young male participants in the study. Brisbane, Australia, 2005.

\begin{tabular}{|c|c|c|c|c|}
\hline Characteristics & Mean & Standard deviation & Minimum & Maximum \\
\hline Age (y) & 21.40 & 2.10 & 18.00 & 25.00 \\
\hline Body weight (kg) & 77.50 & 13.50 & 54.40 & 103.80 \\
\hline Height (m) & 1.76 & 0.07 & 1.60 & 1.89 \\
\hline BMI $\left(\mathrm{kg} / \mathrm{m}^{2}\right)$ & 24.83 & 3.49 & 18.76 & 33.50 \\
\hline RMR (kcal/d) & 1904.40 & 282.10 & 1348.90 & 2583.70 \\
\hline $\mathrm{EE}(\mathrm{kcal} / \mathrm{d})$ & 3626.40 & 613.70 & 2533.30 & 4796.40 \\
\hline $\mathrm{PAL}$ (= EE / RMR) & 1.91 & 0.18 & 1.50 & 2.26 \\
\hline El 4dFR (kcal/d)a & 2726.40 & 525.80 & 1781.30 & 3749.80 \\
\hline El 24hDR (kcal/d)b & 2747.00 & 686.00 & 1440.00 & 4011.00 \\
\hline Individual cut-off & \multicolumn{4}{|c|}{$1.26<\mathrm{El} / \mathrm{RMR}<2.72$} \\
\hline Group cut-off & \multicolumn{4}{|c|}{$1.73<$ El/RMR $<1.98$} \\
\hline
\end{tabular}

a 4dFR: 4-day food record; b 24hDR: 24-hour dietary recall.

BMI: body mass index; RMR: resting metabolic rate; EE: daily energy expenditure; PAL: physical activity level; El: energy intake.

Table 2. Daily macronutrients and energy intake evaluated by 24-hour dietary recall and 4-day food record from 34 young men. Brisbane, Australia, 2005

\begin{tabular}{|c|c|c|c|c|c|c|}
\hline \multirow{3}{*}{ Dietary intake } & \multicolumn{6}{|c|}{ Dietary method } \\
\hline & \multicolumn{3}{|c|}{$24 \mathrm{hDR}$} & \multicolumn{3}{|c|}{$4 \mathrm{dFR}$} \\
\hline & $\mathrm{M}$ & SD & Minimum - Maximum & $\mathrm{M}$ & SD & Minimum - Maximum \\
\hline Proteins (g) & 121.6 & 42.3 & $(51.9-225.0)^{a}$ & 113.3 & 28.5 & $(60.7-178.5)$ \\
\hline Fat $(\mathrm{g})$ & 96.3 & 31.4 & $(32.2-152.5)$ & 96.1 & 20.2 & $60.6-132.5)$ \\
\hline Carbohydrates (g) & 335.8 & 102.3 & $(142.4-591.4)$ & 318.7 & 80.4 & $180.9-545.2)$ \\
\hline $\mathrm{El}(\mathrm{kcal} / \mathrm{d})$ & 2747.0 & 686.0 & $(1440.0-4011.0)$ & 2726.0 & 526.0 & $(1781.0-3750.0)$ \\
\hline El from proteins (\%) & 19.0 & 4.6 & $(12.8-30.3)$ & 18.0 & 3.8 & $(12.3-28.8)$ \\
\hline El from fat $(\%)^{\mathbf{b}}$ & 31.4 & 6.5 & $(18.3-44.1)$ & 32.0 & 5.1 & $(18.5-40.6)$ \\
\hline El from carbohydrates (\%) & 49.1 & 9.3 & $(35.0-68.4)$ & 46.7 & 7.0 & $(32.8-61.5)$ \\
\hline
\end{tabular}

a minimum - maximum; b Energy source $=100 \times$ nutrient intake $(\mathrm{g}) \times$ nutrient energy value/El.

The nutrient energy value for protein, fat and carbohydrate are 4, 9 and $4 \mathrm{kcal} . \mathrm{g}^{-1}$, respectively. El: energy intake; M: mean; SD: standard deviation; 24hDR: 24-hour dietary recall; 4dFR: 4-day food record. 
individual level. Despite the differences being normally distributed (Gaussian), because $95 \%$ of differences fell between mean 1.96 SD, they were too large at individual level (Figure 1).

Three (8.8\%) and seven (20.6\%) URs were identified when El was estimated by $24 \mathrm{hDR}$ and by $4 \mathrm{dFR}$, respectively (Figure 2 ).

The within-participant day to day variation in $\mathrm{El}\left(\mathrm{CV}_{\text {wEl }}\right)$ of individuals is large (Figure 3A). When considering mean daily El from two or three days, the variation decreases with increasing the number of days of dietary assessment (Figure 3B and 3C).

The linear correlation between mean daily $\mathrm{EI}$ and $\mathrm{EE}$ was not significant when El was estimated by $4 \mathrm{dFR}(r=0.29)$ or $24 \mathrm{hDR}(0.001)$.

A
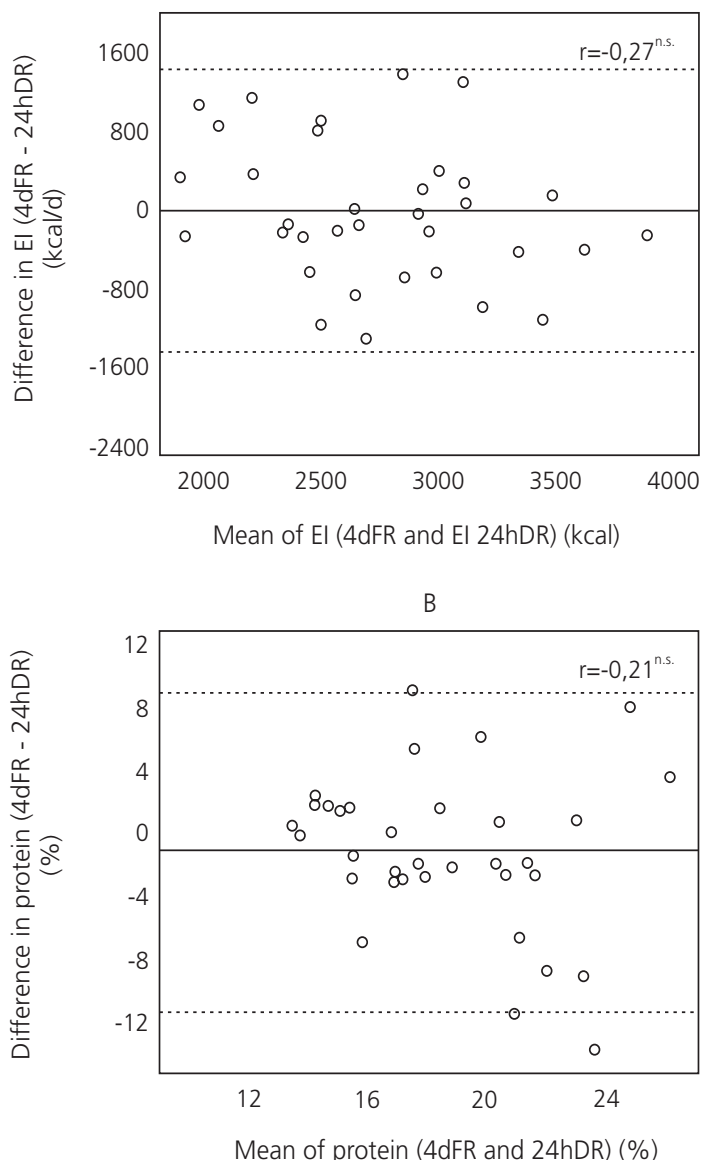

DISCUSSION

There was good agreement between the measurements of energy and macronutrients intake estimated by $24 \mathrm{hDR}$ and $4 \mathrm{dFR}$ at the group level. Similar findings were observed in other studies. The mean differences between the nutrient intake observed in 42 men aged 21 to 65 years with BMI of 21 to $39 \mathrm{kgm}^{-2}$ while in a metabolic facility and that estimated by $24 \mathrm{hDR}$ the following day, ranged from 8.0 to $9.3 \%{ }^{13}$. When 79 men aged 20 to 67 years selected and consumed all foods for a 1-day period under observation and actual intake was determined in the following day by a 24-hour recall, the energy intake was overestimated by $7.6 \%{ }^{14}$. Karvetti \&
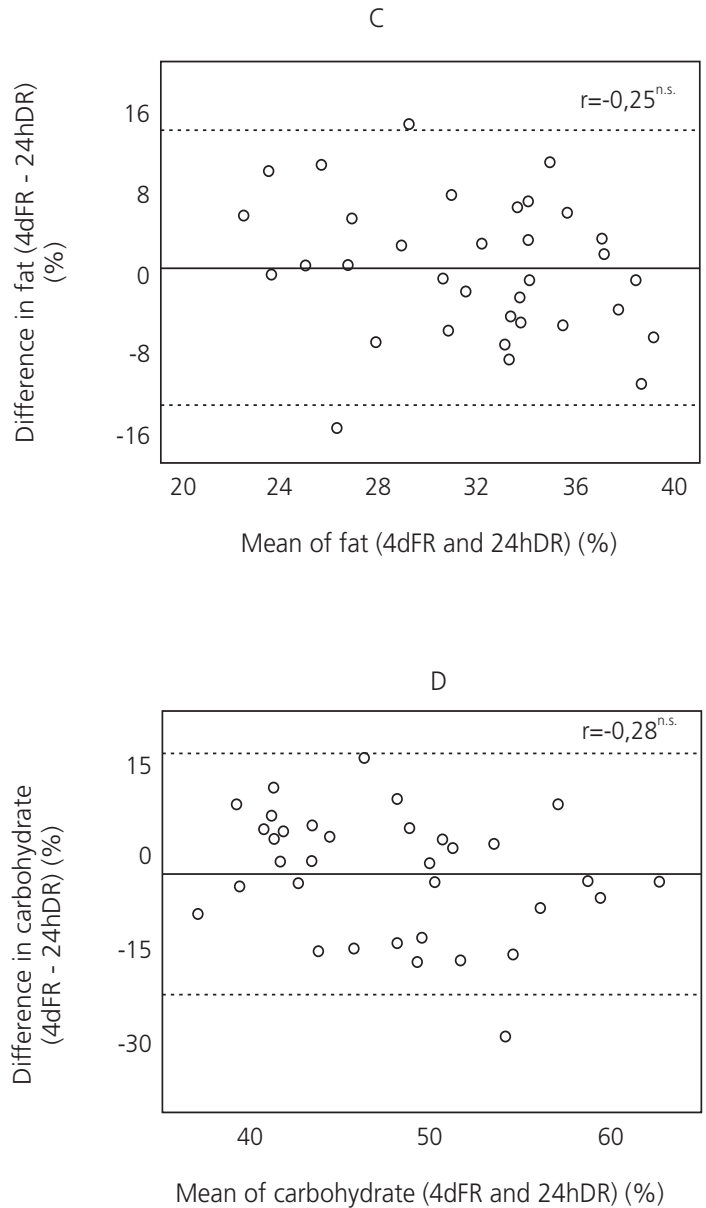

Figure 1. Bland and Altman ${ }^{12}$ plot. Differences in daily energy intake - El (A) protein (B), fat (C), and carbohydrate intake (D) of 34 young men, estimated by 4-day food record (4dFR) and 24-hour dietary recall (24hDR) against the mean of the estimations by both methods. Brisbane, Australia, 2005.

Note: The lines represent the mean difference (solid) and 1.96 standard deviation (dashed). n.s p $>0.05$. 
Knuts ${ }^{15}$ found that El estimated by $24 \mathrm{hDR}$ was overestimated by $3 \%$ in relation to that observed intake in 140 participants including 84 men and 56 women aged 15 to 57 years.

However, the relative and absolute agreement at the group level between $24 \mathrm{hDR}$ and $4 \mathrm{dFR}$ does not necessarily indicate that the methods are valid measurements of food intake. The El estimated from both $24 \mathrm{hDR}$ and $4 \mathrm{dDR}$ methods in the current study was approximately $25 \%$ below EE estimated by 4-day physical activity records.
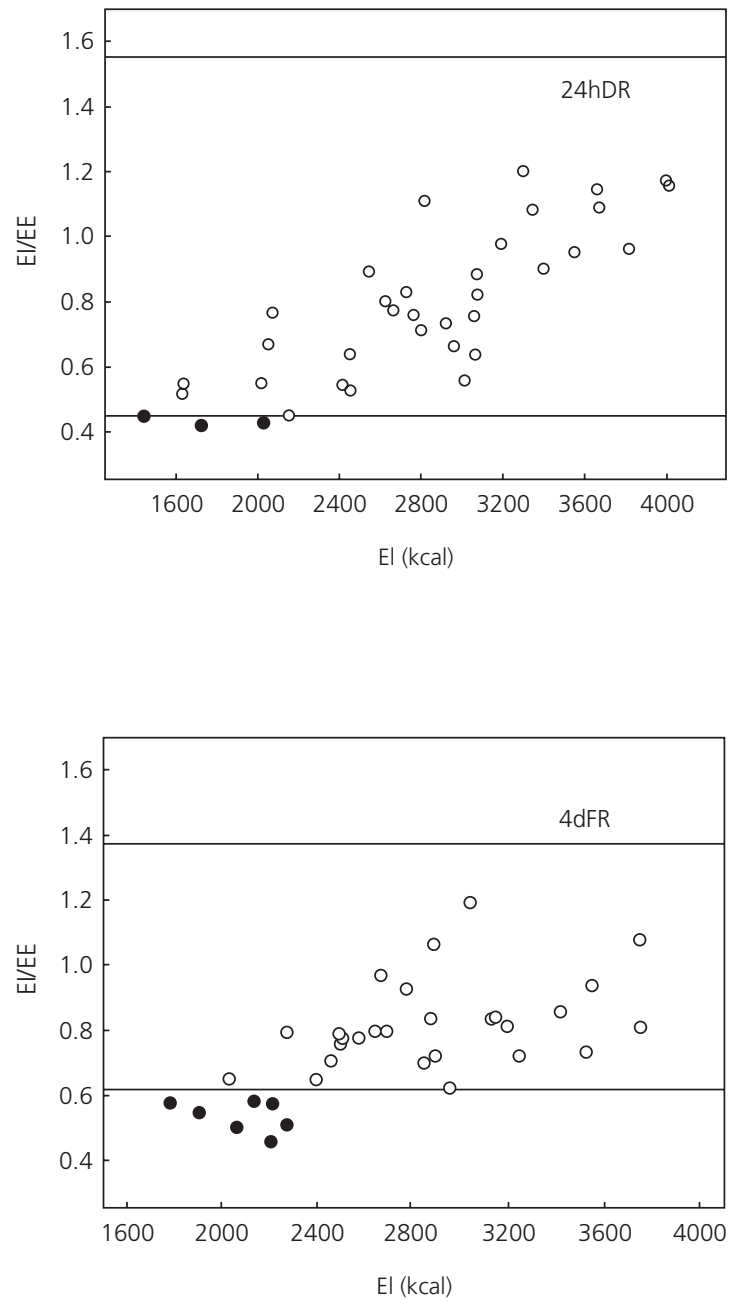

Figure 2. Energy Intake (EI)/Energy Expenditure (EE) against EE in 34 youth men. El was estimated by 24-hour dietary recall (24hDR) (A) or by 4-day food record (4dFR) (B). Brisbane, Australia, 2005.

Note: The lines represent the $95 \%$ confidence limits of El/EE.

• = underreporters: $\mathrm{E} / \mathrm{EE}<0.45$ (A) or $\mathrm{E} / \mathrm{EE}<0.62$ (B).
A

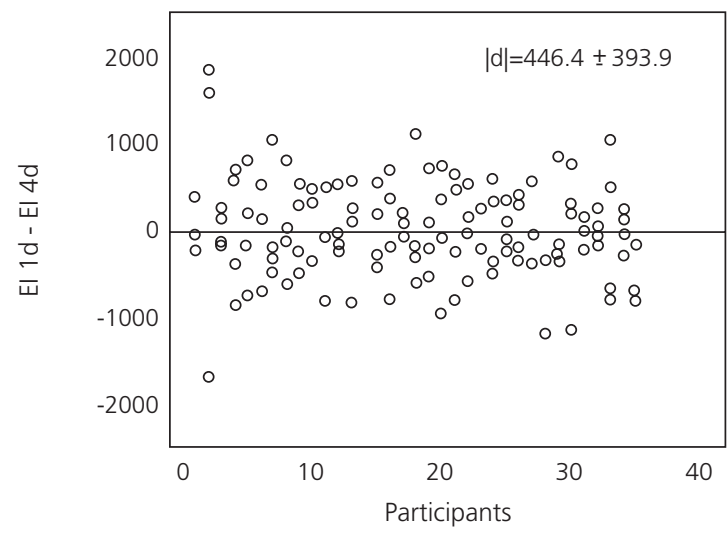

B

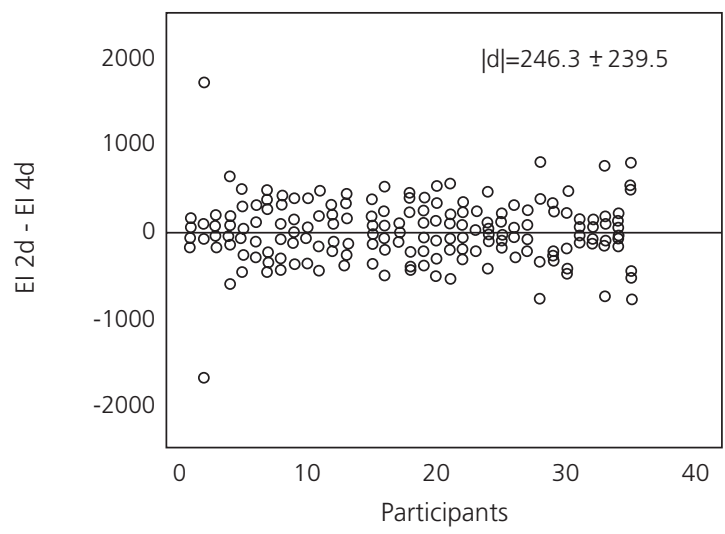

C

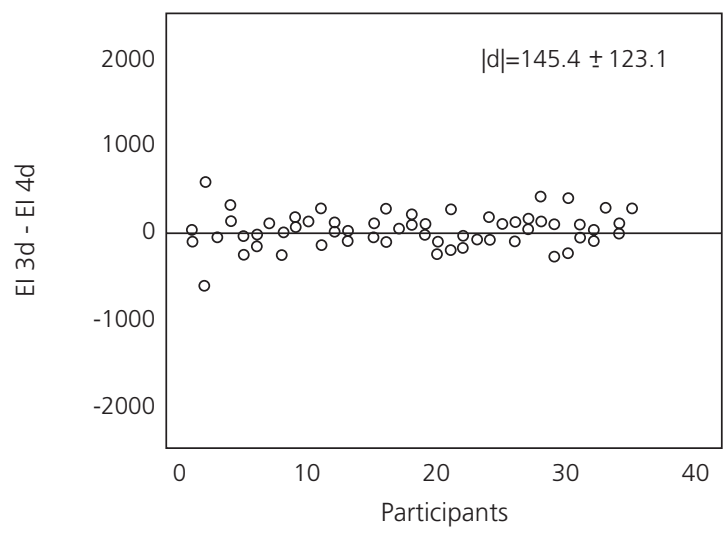

Figure 3. Individual energy intake (EI) variation of 34 youth men estimated by 4-day food record: differences between four days El average (EI 4d) daily EI (EI 1d) (A), two days El average (El $2 \mathrm{~d}$ ) (B) and three days El average (El 3d) (C). $d$ is the absolute difference (mean, standard deviation. Brisbane, Australia, 2005. 
Underestimation of El intake has been found in other studies. Jonnalagadda et al. ${ }^{16}$ found El underestimation of $12 \%$ when $24 \mathrm{hDR}$ was compared to El required to maintain body weight in 78 men and women aged 22 to 67 years. Thirtythree women reported their El as 13\% lower than their observed intake during one day in a metabolic facility ${ }^{17}$.

The El underestimation of 25\% estimated by both food intake methods in relation to $\mathrm{EE}$ found in the current study was higher than that $(12 \%$ or $13 \%)$ found in other studies ${ }^{16,17}$. An overestimation of EE may have occurred. The use of self reported physical activity records to estimate $\mathrm{EE}$ is a limitation of the current study because individuals can easily overestimate or underestimate the time spent in activity and the intensity of the activity ${ }^{18}$. An overestimation of $\mathrm{EE}$ would explain a higher PAL (1.91) compared to the mean (1.85) for men $18-25$ years $^{19}$ when EE was assessed by Double Labeled Water (DLW). A overestimation of EE would also explain the smaller El/EE (0.76) found in the current study compared to that $(0.84)$ found by Livingstone et al. ${ }^{20}$ when analyzing data from 26 studies where El was reported and EE was assessed by DLW. However, if EE was overestimated, it did not appear to have jeopardized the study regarding the number of URs identified because the upper limit of 1.38 for ARs was much higher than the highest El/EE ratio of 1.2 found for one of the participants of the current study. However caution should be taken with the percentage of El underestimation.

At the individual level, there was not good agreement between the measurements of individual intake of energy and macronutrients by $24 \mathrm{hDR}$ and $4 \mathrm{dFR}$. The inaccuracy of $24 \mathrm{hDR}$ for measuring food intake at the individual level was also observed in other studies. Conway et al..$^{13}$ observed a significant variation in the ability of the men to recall food intake and the errors ranged from almost zero to $30 \%$ for El. Karvetti \& Knuts ${ }^{15}$ found that $45 \%$ of participants under- or overestimated their El by more than 20\% compared to their observed food intake.
Besides the difficulty in recalling food on the previous day there is large within-participant day-to-day variation in El which makes $24 \mathrm{hDR}$ inaccurate to measure habitual or usual food intake. Champagne et al. ${ }^{21}$ found day-to-day variation higher than $2500 \mathrm{kcal}^{-\mathrm{d}^{-1}}$ in one participant over a 7-day period. Individual daily EI differed according to the annual average by up to $1670 \mathrm{kcal}^{11}$ and the $\mathrm{CV}_{\text {wEI }}$ ranged from 10 to $50 \%$, with a pooled mean of $26 \%{ }^{22}$. From 14 studies reviewed by Bingham ${ }^{23}$ and Nelson et al. ${ }^{24}, \mathrm{CV}_{\text {wEl }}$ ranged from 14 to $45 \%$, with a pooled mean of $23 \%$. These data are similar to the daily EI variability for $4 \mathrm{dFR}$ data found in the current study which ranged from 3.5 to $52.4 \%$ with a pooled mean of $23.6 \%$.

The daily El variability for $4 \mathrm{dFR}$ data decreased with the increasing of days reporting food intake in the current study, which can be observed in the Figure 3, where the points were closer to the line 0 and consequently the difference between El mean estimated from 3 days and that estimated from 4 days was smaller. Due to smaller variability of El intake estimated with $4 \mathrm{dFR}$, the cut-off interval was smaller $(0.68-1.38$ versus 0.45 1.55) and higher number of individuals (7 versus 3 ) were identified as URs compared to $24 \mathrm{hDR}$.

The smaller number of URs identified with 24hDR than that identified with $4 \mathrm{dFR}$ does not mean that $24 \mathrm{hDR}$ is more accurate to estimate food intake. When food intake of only one day is considered, the within-participant day-to-day variation in $\mathrm{El}$ is very large, leading to a low sensitivity and therefore fewer URs are identified.

There is a tendency subject-specific for food intake underreporting ${ }^{10}$. If a participant is an UR once, it is very likely that he/she will be an UR on other occasions. In the current study, $33 \%$ of UR of $\mathrm{El}$ estimated by $24 \mathrm{hDR}$ underreported $\mathrm{El}$ estimated by $4 \mathrm{dFR}$. High percentage of URs on more than one occasion has been identified when $\mathrm{El}$ is assessed by the same ${ }^{1,25}$ or by different methods ${ }^{5}$. When 24-hour dietary was used to estimate El, $55 \%$ of male URs on the first 24-hour 
dietary also under-reported on the second $24 \mathrm{hDR}$, 1 month after ${ }^{1}$. Using either diet history or $7 \mathrm{dFR}$ method to estimate $\mathrm{El}, 34 \%$ of men underreported by both food intake methods 5 .

Different measurement contexts and skills required in recording and reporting may have accounted for differences on measurements estimated with $24 \mathrm{hDR}$ and $4 \mathrm{dFR}$ at the individual level. The $24 \mathrm{hDR}$ relies on memory and "bad" dietary intake is less likely to be reported to an interviewer than on a self-report3,26.

On the other hand, $4 \mathrm{dFR}$ may be more difficult to participants to complete than the $24 \mathrm{hDR}$. It is widely recognized that food self reports are subject to errors and biases ${ }^{11}$. In addition, there are some participants' common errors when reporting food intake including: a) overeating, or most commonly undereating, which are an increase, or a reduction, respectively, in food intake ${ }^{2,17,26-29}$, b) under or over-estimation due to errors in the estimation of portion size and lack of knowledge of the composition of mixed dishes ${ }^{30}$ and c) mis-reporting including under- and overreporting due to forgotten meals and failure to record because of the burden of recording everything that was eaten ${ }^{29}$. Over $45 \%$ of participants admitted to have altered their diet consciously due to feeling embarrassed about recording specific food and / or due to much effort after having weighed and recorded food intake over 7 days ${ }^{29}$.

In conclusion, there was good agreement between the measurements of energy and macronutrients intake by $24 \mathrm{hDR}$ and $4 \mathrm{dFR}$ at the group level, but not at the individual level. Therefore $24 \mathrm{hDR}$ can be used to assess a food intake of a group but not their individual intake. About $20 \%$ and $9 \%$ of participants underreported their El by $4 \mathrm{dFR}$ and $24 \mathrm{hDR}$, respectively considering the $95 \%$ confidence interval for EI/EE criteria. Over $30 \%$ of El URs assessed by $24 \mathrm{hDR}$ underreported their El assessed by 4dFR showing that underreporting may be subject-specific and it appears that is more difficult to retrieve valid dietary data from some people than others.

\section{ACKNOWLEDGEMENTS}

The authors thank the voluntary participants and the Queensland University of Technology for the use of its Laboratories and facilities. S.C. Liberato acknowledges financial support from the Conselho Nacional de Desenvolvimento Científico e Tecnológico. (processo 140931/2001-5) and (processo 201075/03-2).

\section{CONTRIBUTIONS}

S.C. LIBERATO planned, executed the study, analyzed the data, prepared the manuscript and participated in reviewing the manuscript. J. BRESSAN participated in planning the study and reviewing the manuscript and A.P. HILLS participated in planning the study, reviewing the manuscript and obtained the funds.

\section{REFERENCES}

1. Briefel RR, Sempos CT, McDowell MA, Chien S, Alaimo K. Dietary methods research in the third National Health and Nutrition Examination Survey: underreporting of energy intake. Am J Clin Nutr. 1997; 65(4 Suppl):1203S-9S.

2. Biro G, Hulshof KF, Ovesen L, Amorim Cruz JA. Selection of methodology to assess food intake. Eur J Clin Nutr. 2002; 56(Suppl2):S25-32.

3. Hoidrup S, Andreasen AH, Osler M, Pedersen AN, Jorgensen LM, Jorgensen $T$, et al. Assessment of habitual energy and macronutrient intake in adults: comparison of a seven day food record with a dietary history interview. Eur J Clin Nutr. 2002; 56(2):105-13.

4. Edington J, Thorogood M, Geekie M, Ball M, Mann J. Assessment of nutritional intake using dietary records with estimated weight. J Hum Nutr Diet. 1989; 2(6):407-14.

5. Kortzinger I, Bierwag A, Mast M, Muller MJ. Dietary underreporting: validity of dietary measurements of energy intake using a 7-day dietary record and a diet history in non-obese subjects. Ann Nutr Metab. 1997; 41(1):37-44.

6. Howat PM, Mohan R, Champagne C, Monlezun C, Wozniak P, Bray GA. Validity and reliability of reported dietary intake data. J Am Diet Assoc. 1994; 94(2):169-73.

7. Weir JB. New methods for calculating metabolic rate with special reference to protein metabolism. J Physiol. 1949; 109(1-2):1-9. 
630 | S.C. LIBERATO et al.

8. Bouchard C, Tremblay A, Leblanc C, Lortie G, Savard $R$, Theriault $G$. A method to assess energy expenditure in children and adults. Am J Clin Nutr. 1983; 37(3):461-7.

9. Black AE. The sensitivity and specificity of the Goldberg cut-off for El:BMR for identifying diet reports of poor validity. Eur J Clin Nutr. 2000; 54(5):395-404.

10. Black $A E$, Cole TJ. Biased over- or under-reporting is characteristic of individuals whether over time or by different assessment methods. J Am Diet Assoc. 2001; 101(1):70-80.

11. Black AE. Critical evaluation of energy intake using the Goldberg cut-off for energy intake:basal metabolic rate. A practical guide to its calculation, use and limitations. Int J Obes Relat Metab Disord. 2000; 24(9):1119-30.

12. Bland JM, Altman DG. Statistical methods for assessing agreement between two methods of clinical measurement. Lancet. 1986; 1(8476): 307-10.

13. Conway JM, Ingwersen LA, Moshfegh AJ. Accuracy of dietary recall using the USDA five-step multiplepass method in men: an observational validation study. J Am Diet Assoc. 2004; 104(4):595-603.

14. Ard JD, Desmond RA, Allison DB, Conway JM. Dietary restraint and disinhibition do not affect accuracy of 24-hour recall in a multiethnic population. J Am Diet Assoc. 2006; 106(3):434-7.

15. Karvetti RL, Knuts LR. Validity of the 24-hour dietary recall. J Am Diet Assoc. 1985; 85(11):1437-42.

16. Jonnalagadda SS, Mitchell DC, Smiciklas-Wright $\mathrm{H}$, Meaker KB, van Heel N, Karmally W, et al. Accuracy of energy intake data estimated by a multiple-pass, 24-hour dietary recall technique. J Am Diet Assoc. 2000; 100(3):303-8; quiz 9-11.

17. Poppitt SD, Swann D, Black AE, Prentice AM. Assessment of selective under-reporting of food intake by both obese and non-obese women in a metabolic facility. Int J Obes Relat Metab Disord. 1998; 22(4):303-11.

18. Ainslie PN, Reilly T, Westerterp KR. Estimating human energy expenditure: a review of techniques with particular reference to doubly labelled water. Sports Med. 2003; 33(9):683-98.

19. Black AE, Coward WA, Cole TJ, Prentice AM. Human energy expenditure in affluent societies: an analysis of 574 doubly-labelled water measurements. Eur J Clin Nutr. 1996; 50(2):72-92.

20. Livingstone MB, Prentice AM, Coward WA, Strain JJ, Black AE, Davies PS, et al. Validation of estimates of energy intake by weighed dietary record and diet history in children and adolescents. Am J Clin Nutr. 1992; 56(1):29-35

21. Champagne CM, Bray GA, Kurtz AA, Monteiro JB, Tucker E, Volaufova J, et al. Energy intake and energy expenditure: a controlled study comparing dietitians and non-dietitians. J Am Diet Assoc. 2002; 102(10):1428-32.

22. Black AE, Prentice AM, Coward WA. Use of food quotients to predict respiratory quotients for the doubly-labelled water method of measuring energy expenditure. Hum Nutr Clin Nutr. 1986; 40(5):381-91.

23. Bingham SA. The dietary assessment of individualsç methods, accuracy, new techniques and recommendations. Nutr Abstr Rev. 1987; 57(10): 705-42.

24. Nelson M, Black AE, Morris JA, Cole TJ. Betweenand within-subject variation in nutrient intake from infancy to old age: estimating the number of days required to rank dietary intakes with desired precision. Am J Clin Nutr. 1989; 50(1):155-67.

25. McKenzie DC, Johnson RK, Harvey-Berino J, Gold BC. Impact of interviewer's body mass index on underreporting energy intake in overweight and obese women. Obes Res. 2002; 10(6):471-7.

26. Hebert JR, Ebbeling CB, Matthews CE, Hurley TG, Ma Y, Druker S, et al. Systematic Errors in MiddleAged Women's Estimates of Energy Intake: comparing three self-report measures to total energy expenditure from doubly labeled water. Ann Epidemiol. 2002; 12(8):577-86.

27. Asbeck I, Mast M, Bierwag A, Westenhofer J, Acheson KJ, Muller MJ. Severe underreporting of energy intake in normal weight subjects: use of an appropriate standard and relation to restrained eating. Public Health Nutr. 2002; 5(5):683-90.

28. Black AE, Prentice AM, Goldberg GR, Jebb SA, Bingham SA, Livingstone MB, et al. Measurements of total energy expenditure provide insights into the validity of dietary measurements of energy intake. J Am Diet Assoc. 1993; 93(5):572-9.

29. MacDiarmid JI, Blundell JE. Dietary under-reporting: what people say about recording their food intake. Eur J Clin Nutr. 1997; 51(3):199-200.

30. Vuckovic N, Ritenbaugh C, Taren DL, Tobar M. A qualitative study of participants' experiences with dietary assessment. J Am Diet Assoc. 2000; 100(9):1023-8.

Received on: 3/9/2007

Final version resubmitted on: 3/7/2008 Approved on: 8/10/2008 